\title{
1. In defense of liberal feminism ${ }^{1}$
}

\author{
Sylvia A. Law
}

This chapter describes and defends liberal feminism and, more specifically, the liberal feminist commitments to an expansive conception of women's liberty and women's equality. Liberty and equality have been the central components of liberalism from Mill and Locke through to Dworkin and Rawls. Non-feminist liberalism rarely focuses on what it means to extend liberty and equality to women. Feminism, on the other hand, in all forms, has been committed to women's well-being. But it has fallen to liberal feminists, in contrast to other forms of feminism, to focus on the difficulties and challenges of securing the liberal values of liberty and equality for women. Liberal feminism, accordingly, is the branch of liberalism committed to women's liberty and equality and the branch of feminism committed to the attainment of these liberal values for women.

This chapter discusses liberal feminism, with a particular focus on U.S. legal and constitutional history. The chapter first reviews the relationship between liberal political theory and feminism in the United States during three periods: the eighteenth-century constitutional founding; the nineteenth-century Civil War; and the 'Second Wave' of feminism that began in the 1970s. By the 1990s, it became commonplace to understand liberalism as requiring women's equality and liberty. Liberalism and feminism had forged to create a powerful political and theoretical movement - liberal feminism - that vastly improved women's lives. Many of those gains, however, are now under attack. Current political movements and forces are undermining women's equal rights to health care, to physical security and protection against assault, and to economic well-being. At the same time, women's resistance to patriarchy is fierce. The second section of the chapter considers the challenges to women's equality and liberty - and thus to both liberalism and feminism - posed by these political winds. Finally, the chapter attempts to defend the liberal feminist commitment to liberty and equality against this direct and hostile assault.

1 Parts of this chapter elaborate ideas first introduced in my essay Liberalism and Feminism included in the collection FEMINIST JURISPRUDENCE IN THE UNITED STATES AND ASIA: A Transpacific Dialogue (Cynthia Grant Bowman and Yu Xingzhong eds., 2017) published in Chinese. 


\section{LIBERALISM AND FEMINISM IN FORMATIVE AMERICAN MOMENTS OF CONSTITUTIONALISM}

\section{A. The Constitutional Founding}

Against a long tradition that conceived of legitimacy and power as flowing from God or the monarch, the eighteenth-century founders of the American Republic were revolutionary in creating a constitution where all lawful power derives from the people: the people themselves are sovereign and self-governing. This political theory of selfgovernance was influenced by ideas that emanated from the coinciding Enlightenment era, including an understanding of knowledge and values as grounded in accumulated experience, and a belief in progress through rational questioning and dialogue. ${ }^{2}$ These ideas eventually came to be understood as a part of the liberal tradition. The idea of self-governance the founders eventually embraced, however, rested on two seemingly conflicting elements: Though the state was to be controlled by the will of the majority, the power of the state would be strictly limited by the non-majoritarian precepts of a constitutional structure and guarantees protecting specified individual liberties from state infringement. ${ }^{3}$ The constitutional structures that limit state power include the division of power among the legislative, executive and judicial branches at the federal level and the allocation of power between the federal government and the states. ${ }^{4}$ The liberties protected from popular will include freedom of conscience, speech and assembly, the right to be free from unreasonable searches, numerous rights protecting people accused of wrongdoing, and due process for people injured by state actions. ${ }^{5}$ An independent judiciary was regarded as necessary to enforce these structural and substantive constitutional limits. In addition to forming the heart of the American political system, the ideas of popular democracy, constitutional limits on state power, rule of law, respect for facts and dialogue and an independent judiciary have come to form the heart of liberalism. Each of these concepts is complex and contested.

The eighteenth-century liberal vision was blind in many respects. First, as discussed in more detail below, it was non-feminist, and even anti-feminist, in assuming that the basic unit of political participation was the male-headed nuclear family, not the individual person. Within the family, women were assigned, on the basis of status, to perform the essential work of production, reproduction, maintenance, consumption and acculturation in the home. Home and family, the core social units upon which liberalism was built, were constructed on the premise that women were not active citizens or full people. ${ }^{6}$ The eighteenth-century founding vision aimed to maximize liberty and equality, but it did not extend that vision to women. Second, the

2 See, e.g., JOHN LOCKE, AN ESSAY CONCERNING HUMAN UNDERSTANDING 424-607 (Roger Woolhouse ed., 2004) (1689). (1690).

3 See John Locke, Two Treatises of Government 141-265 (Peter Laslett ed., 1988)

4 U.S. ConsT. art. $1, \S 1 ; i d$. art. $2, \S 1 ; i d$. art. $3, \S 1$.

5 U.S. Const. amends. I, IV, V, VI, VII, VIII; id. amend. XIV, § 1.

6 Carl N. Degler, At Odds: Women and the Family in America from the RevoluTION TO THE PRESENT 179-209 (1980). 
eighteenth-century constitution accepted human slavery and restricted the suffrage to white men. ${ }^{7}$ Third, eighteenth-century liberalism placed a high value on private property, freedom of contract and free markets. As a result of intense political struggle in the nineteenth century and the first few decades of the twentieth, including the Civil War and constitutional amendments, these three flaws - the embrace of patriarchy, the acceptance of slavery and the high value accorded to markets - were corrected, or at least acknowledged, to some degree.

Two other limits of the eighteenth-century liberal vision, however, persist to this day. First, modern liberalism, like its eighteenth-century counterpart, perceives the state as the primary threat to individual liberty and human flourishing. Concentrated private power, however, can also threaten democracy, liberty, equality and other important values. Although popular democracy can place limits on private power, the Constitution generally does not do so. Second, and relatedly, the substantive rights protected by a liberal constitution are negative constraints on state power, rather than affirmative obligations to provide the material and social support for human well-being. Again, the people through democratic action may choose to provide citizens the support and services they need, but a liberal constitution generally does not require the people to do so.

With respect to women, the liberalism of the eighteenth century was extremely restrictive and assumed that in public, economic and political life, women were represented by their husbands or fathers. The married woman was civilly dead, her legal identity merged into that of her husband. She could not sue, be sued, enter into contracts, make wills, keep her own earnings or control her own property. Her husband had the right to chastise her, restrain her freedom and force her to engage in sexual intercourse against her will. Because, under liberal theory, political rights were tied to ownership of property, women had no political voice. ${ }^{8}$ While this regime denied women's voices, historians have richly documented manifold acts of resistance and rebellion, as well as material and intellectual contributions by women of all races and classes in this era. ${ }^{9}$

\section{B. The Nineteenth Century: First Wave Feminism and Abolition}

During the nineteenth century, conceptions of family and women changed dramatically with urbanization and industrialization. Average family size declined from seven

7 The Thirteenth Amendment outlawed slavery and involuntary servitude in 1855. U.S. CONST. amend. XIII, $\S 1$. The right to vote was expanded by the ratification of the Fifteenth Amendment in 1870 and the ratification of the Nineteenth Amendment in 1920. U.S. ConST. amend. XV, § $1 ; i d$. amend. XIX.

82 Blackstone's COMMENTARIES: With Notes OF REFERENCE tO THE CONSTITUTION AND LAWS, OF THE FEDERAL GOVERNMENT OF THE UNITED STATES AND OF THE COMMONWEALTH OF VIRGINIA 442-44 (St. George Tucker ed., 1803); Wendy W. Williams, The Equality Crisis: Some Reflections on Culture, Courts and Feminism, 7 WOMEN's RTS. L. REP. 175, 176-77 (1982).

9 See, e.g., MARy Beth Norton, Liberty's Daughters: The ReVOlutionary EXPeriENCE OF AMERICAN WOMEN, 1750-1800 (1980); LindA K. KeRBER, WOMEN OF THE REPUbliC: INTELLECT AND IDEOLOGY IN REVOLUTIONARY AMERICA (1980). 
children in 1800 to three in $1900 .{ }^{10}$ For the first time, respected political philosophers argued that discrimination against women was irrational, unjust and socially harmful. ${ }^{11}$ Also, from the 1830s, the abolitionist cause drew women into public life. ${ }^{12}$ Some of the women who met in the anti-slavery movement perceived parallels between the subjugation and disenfranchisement of black people and the oppression of women. In 1848 the First Women's Rights Convention, held in Seneca Falls, New York, issued a proclamation that closely tracked the original Declaration of Independence. ${ }^{13}$ Women were further invigorated to fight for equality after the adoption of three constitutional amendments between 1865 and 1870. The Thirteenth Amendment prohibited slavery and involuntary servitude; the Fourteenth Amendment prohibited states from denying people the privileges and immunities of citizenship or the equal protection of the law or from depriving them of life, liberty or property without due process of law; and the Fifteenth Amendment provided that the right to vote should not be denied on account of race, color or previous condition of servitude. ${ }^{14}$

In the late nineteenth century women achieved significant liberal victories. States repudiated the notion that married women were civilly dead and allowed them to own property. A few extraordinary women entered some institutions of higher education. Across the country, women campaigned for women's suffrage and won the right to vote in some states. However, when women sought to invoke the grand liberal ideals represented by the Reconstruction Amendments to claim the right to vote, to practice law and engage in other professions, to be judged by juries that did not exclude women and to resist other arbitrary denials of liberty and equality, their claims were rebuffed. ${ }^{15}$ After a century of struggle, women, finally, won a constitutional amendment giving them the right to vote in $1920 .{ }^{16}$ But neither women's suffrage nor the Reconstruction Amendments changed the economic, political or social situation of women - rich or poor, black or white - until the rise of the so-called Second Wave feminist movement in the 1970s. ${ }^{17}$

The Constitution, laws and social practices of the United States remained blatantly sexist well into the twentieth century. In 1943 the Supreme Court upheld a law excluding women from tending bar, unless she was the wife or daughter of the owner. ${ }^{18}$ As late as the 1960s, qualified women were openly excluded from desirable jobs and

10 Max Rosner, Fertility Rate, OUR WORLD IN DATA (Dec. 2, 2017), https://ourworldindata. org/fertility-rate.

11 Mary Wollstonecraft, A Vindication of the Rights of Women, in THE FEMINIST PAPERS: From Adams to Beauvorr 40-85 (Alice Rossi ed., 1988); John Stuart Mill, The Subjection of Women, in id.

12 Eleanor Flexner \& Ellen Fitzpatrick, Century of Struggle: The Women's Rights MOVEMENT IN THE UNITED STATES 195-207 (1996).

13 Susan B. Anthony \& Elizabeth Cady Stanton, Selected Papers of Elizabeth Cady Stanton And Susan B. Anthony, In the School of Anti-Slavery, 1840 to 1966 (Ann D. Gordon ed., 1997).

14 U.S. CONST. amend. XII, § 1; id. amend. XIV, § 1; id. amend XV, § 1.

15 See FleXNer \& FitZPATRICK, supra note 12.

16 U.S. CONST. amend. XIX.

17 See Sylvia A. Law, The Founders on Families, 39 U. FlA. L. ReV. 583 (1987).

18 Goesaert v. Cleary, 335 U.S. 464, 467 (1948). 


\section{8}

educational opportunities in the legal profession. ${ }^{19}$ The law excused women from jury duty, military service and other civic obligations historically associated with full citizenship. ${ }^{20}$ Abortion was a crime in most states, and abortion and contraception were unavailable to many women, particularly the poor, the young, the uneducated and those living in rural areas. ${ }^{21}$ Criminal law was defined and enforced in ways pervasively damaging to women, particularly in relation to rape, marital rape, sexual harassment ${ }^{22}$ and domestic violence. ${ }^{23}$ Family law devalued women in relation to child custody and support, as well as marital property. Society failed to support the work of caring for the frail, both young and old, and instead expected that women bear the burden of this essential work, without recognition or compensation. ${ }^{24}$ All these forms of discrimination violated basic liberal norms of equality and liberty.

In the 1970s politically active women in the United States were deeply involved in the civil rights movement for racial equality, the popular opposition to the U.S. war in Vietnam and the fight for economic justice for the poor. Women made significant contributions and provided important leadership in all of these struggles, but women's influence was often devalued or claimed by men. Like their sisters in the eighteenthcentury movements for the abolition of slavery, women in the 1970s saw parallels between themselves and other groups subject to irrational discrimination and subjugation, as well as possibilities for change through study, education, organization, and political and legal mobilization..$^{25}$

\section{Second Wave Feminism from the 1970s to the Present}

Second Wave liberal feminists of the 1970s utilized many methodologies to address a range of substantive issues. ${ }^{26}$ Consciousness raising, for example, was a core methodology of Second Wave feminists. For many, regularly meeting with a small group of women to share personal stories and understand those experiences in a larger political context was powerful in generating both understanding and action. Feminists also urged federal and state courts to redress claims of gender discrimination, using novel theories

19 See Cynthia Bowman, The Entry of Women into Wall Street Law Firms: The Story of Blank v. Sullivan and Cromwell, in WoMEN AND THE LAW: STORIES 415, 416-19 (Elizabeth M. Schneider and Stephanie M. Wildman eds., 2011).

20 See, e.g., Hoyt v. Florida, 368 U.S. 57, 68 (1961) (exempting women from jury duty); Rostker v. Goldberg 453 U.S. 47, 83 (1981) (holding that it is constitutional to require only men to register for the draft).

21 See Rhonda Copelon and Sylvia A. Law, 'Nearly Allied to Her Right to Be'-Medicaid Funding for Abortion: The Story of Harris v. McRae, in WOMEN AND THE LAW STORIES 207 (Elizabeth M. Schneider and Stephanie M. Wildman eds., 2011).

22 See Catherine A. MacKinnon, Sexual Harassment of Working Women: A Case OF SEX DisCRIMINATION (1979).

23 Reva Siegel, 'The Rule of Love': Wife Beating as Prerogative and Privacy, 105 YAlE L. J. 2117, 2122 (1996) (tracing common law roots of domestic violence).

24 See, e.g., Chai R. Feldblum, Home Health Care for the Elderly: Programs, Problems and Potentials, 22 HARV. J. LEG. 193, 195 (1985).

25 Id.

26 For an excellent description of liberal feminism of the 1970s, see ZILLAH R. EISENSTEIN, FEMINISM AND SEXUAL EQUALITY: CRISIS IN LIBERAl AMERICA (1984). 
under both statutes and constitutions. Others sought legislative change and became involved in electoral politics. Some sought to change cultural understandings. These methodologies were not mutually exclusive and were often used together.

Pregnancy discrimination is one complex example of how liberal feminists used the many tools in the feminist kit to fight for change. In the 1970s, employers, public and private, commonly discriminated against pregnant women even when the woman was fully competent to do her job. Women were fired when the pregnancy showed, so as not to embarrass customers, students or co-workers. ${ }^{27}$ Employment-based health insurance commonly excluded coverage for childbirth on the ground that childbirth was a lifestyle choice, not a medical need. Disability plans, provided to many workers, paid for leave necessitated by everything except pregnancy. ${ }^{28}$ If a worker was disabled because of a prostate condition, a skiing accident or anything else, the employer paid. But if a worker was physically disabled because of pregnancy, the employer would not give her leave.

Feminist lawyers, led by Ruth Bader Ginsburg, now a justice on the US Supreme Court, challenged these discriminatory practices as a form of gender discrimination prohibited by the Fourteenth Amendment's guarantee of the equal protection of the laws. The Supreme Court held that excluding pregnancy-related disabilities from an otherwise comprehensive benefit for people with disabilities did not constitute gender discrimination. ${ }^{29}$ The program distinguished, the Court said, between pregnant people and non-pregnant people and had nothing to do with gender discrimination. ${ }^{30}$ That decision profoundly violated core liberal commitments to equal treatment, not to mention logic and the English language. Since the Supreme Court's word on the Constitution is final, in response, liberal feminists mobilized public understanding that discrimination against pregnant 'people' was in fact discrimination against women. They persuaded Congress to adopt the Pregnancy Discrimination Act as an amendment to Title VII, prohibiting sex discrimination in employment. ${ }^{31}$

Second Wave feminists achieved impressive changes in law and culture. Constitutional norms were interpreted to strike down state policies that overtly discriminated on the basis of gender. The numbers and influence of women in every area of human endeavor increased exponentially, though women are still underrepresented in desirable and influential positions. ${ }^{32}$ As chapters in this volume by Susan Frelich Appleton, Deborah Tuerkheimer and Victoria Nourse recount, important reforms in family law

27 Flora Davis, Moving the Mountain: The Women's Movement in America Since 1960299 (1999).

28 Id.

29 Geduldig v. Aiello, 417 U.S. 484, 494-95 (1974).

30 Id. at 496-97.

31 Pub. L. No. 95-555, § 1, 92 Stat. 2076 (codified at 42 U.S.C. $\$ \S 2000 \mathrm{e}(\mathrm{k}), 2000 \mathrm{e}-2$, 20000e-3 (1982)).

32 See, e.g., Women In Elective Office, CTR. FOR AM. WOMEN AND POL., http:// www.cawp.rutgers.edu/women-elective-office-2018; Matt Egan, Still Missing: Female Business Leaders, CNN (Mar. 24, 2015), http://money.cnn.com/2015/03/24/investing/female-ceo-pipelineleadership/; Tiffani Lennon, Benchmarking Women's Leadership in the United States, U. DENVER (Aug. 18, 2013), https://womenscollege.du.edu/media/documents/Benchmarking WomensLeadershipintheUS.pdf. 
and criminal law were implemented. Through Title IX of the Civil Rights Act, prohibiting sex discrimination in education, girls were able to gain access to athletic activities that traditionally were only for boys. ${ }^{33}$ Access to abortion and contraception was transformed from a crime to a right, ${ }^{34}$ albeit one that remains highly contested.

Liberal feminism, however, has faced a harsh backlash. Since Second Wave feminism precipitated deep social, economic and political change, backlash is not surprising. Change is disconcerting. Conservative defenders of patriarchal family arrangements, as well as those who benefit culturally and economically from traditional assumptions of white male privilege, have been understandably resistant. This backlash has led us to a time where both liberalism and feminism are under constant assault.

\section{CONTEMPORARY ATTACKS ON WOMEN'S EQUALITY AND LIBERTY: THE BACKLASH TO LIBERAL FEMINISM}

The election of Donald Trump in 2016 is perhaps the epitome of the twenty-firstcentury backlash to liberal feminism. Full review of the Trump threat to liberal democracy is beyond the scope of this chapter, but, in short, Trump and many who support him deny core liberal values. Popular democracy is challenged by voter suppression, tolerance of clandestine Russian interference in the electoral process and the enormous, secret influence of concentrated wealth, for example. Executive deference to the rule of law, as well as respect for facts, science and rational dialogue, are at an all-time low. While in the past half-century, explicit, open, state-sponsored racism and sexism have been condemned as legally and culturally inconsistent with core liberal American values, Trump's blatant racism and sexism is excused by his many supporters as frank speaking, irreverent personal style or simply worth tolerating in pursuit of other goals.

The Trump presidency highlights various forms of backlash to liberalism, feminism and liberal feminism. Three forms of backlash, however, have been particularly devastating. First, the widespread rejection, by both officials in government and a large swath of the American public, of the core liberal feminist claim that individuals are entitled to control their reproductive lives undermines all of women's other gains. Second, the continued existence of pervasive sexual harassment is devastating to women's health and well-being. It undermines women's liberty in the public sphere and possibilities for advancement and fulfillment in the worlds of work and school. Third, the deepening disparity in wealth, income and opportunity between the people at the top and those at the bottom has a particularly harsh impact on the equality of women and people of color.

33 See Title IX \& Issues: What is Title IX, WomEn's Sports Found. (Sept. 20, 2011), http://www.womenssportsfoundation.org/en/home/advocate/title-ix-and-issues/what-is-title-ix/titleix-myths-and-facts.

34 Roe v. Wade, 410 U.S. 113, 164-67 (1973). 


\section{A. Reproductive Health Care for Women}

In the decades prior to the rise of Second Wave feminism, the Catholic Church led opposition to contraception. ${ }^{35}$ The Democratic party, which included a disproportionately large number of Catholics, promoted this view in the public sphere. The Republican party, by contrast, favored access to contraception as a matter of individual liberty and, for some, concern about over-population, particularly among the 'wrong' people. ${ }^{36}$ Because Catholics are a minority, and many do not follow the teachings of their Church in relation to contraception, state bans on contraception persisted only in states that were strongly Democratic and Catholic. In 1965 the Supreme Court held that the Constitution protects the right of married couples to use contraception in Griswold v. Connecticut. When the case was decided, only Connecticut and Massachusetts prohibited adult women from obtaining contraception. ${ }^{37}$ After Griswold, the Church resolved that, even though contraception is a mortal sin in the eyes of the Church, it should discourage contraception through education and example, rather than efforts to mobilize state criminal authority to restrict access to contraception. ${ }^{38}$

The Republican party soon joined the Catholic Church in opposing access to reproductive health care. Until Senator Joseph McCarthy was censured in 1954 for conduct 'contrary to Senatorial traditions,' opposition to Communism was a core moral principle of the Republican party. ${ }^{39}$ The brilliant Phyllis Schlafly, who had built an influential career within the Republican party fighting Communism, appreciated that the party needed a new moral core. She found it in opposition to the Equal Rights Amendment (ERA) and to abortion. ${ }^{40}$ As recently as 1976, 'public opinion polls showed that Republican voters were, on average, more pro-choice than their Democratic counterparts. ${ }^{41}$ Opposition to the ERA was not an enduring issue. By the time it was defeated in 1982, after a decade of debate, the Supreme Court had interpreted the Fourteenth Amendment to prohibit most explicitly sex-based laws that the ERA would have condemned..$^{42}$ But disagreement about abortion remained centrally controversial. In 1976 the Republican party adopted a plank calling for a constitutional amendment to

35 See David Garrow, Liberty \& SeXuality: The Right to Privacy and the Making OF RoE v. WADE (1994).

36 Id.

37 Griswold v. Connecticut, 381 U.S. 479, 485 (1965).

38 Charles E. Curran, Toward an American Catholic Moral Theology 29 (1987).

39 The Censure Case of Joseph McCarthy of Wisconsin (1954), U.S. SENATE HIST. OFF., https://www.senate.gov/artandhistory/history/common/censure_cases/133Joseph_McCarthy.htm. For information on The Red Scare, see Red Scare, HISTORY, http://www.history.com/topics/coldwar/red-scare.

40 Douglas Martin, Phyllis Schlafly, 'First Lady' of Political March to the Right, Dies at 92, N.Y. TimeS (Sept. 5, 2016) https://www.nytimes.com/2016/09/06/obituaries/phyllis-schlaflyconservative-leader-and-foe-of-era-dies-at-92.html.

41 Daniel K. Williams, The GOP's Abortion Strategy: Why Pro-Choice Republicans Became Pro-Life in the 1970s, 23 J. POL'Y HIST. 513, 513 (2011).

42 See Ann E. Freedman and Sylvia A. Law, Thomas I. Emerson: A Pioneer for Women's Equality, 38 CASE W. RES. L. REV. 539 (1988). 
protect human life from the moment of fertilization. ${ }^{43}$ Moderate Republicans sought a state's rights approach to the issue but were rebuffed. Republicans sought to appeal to Catholic voters and were sometimes successful both with them and with fundamentalist Protestants. Adherence to this plank has since become a litmus test for Republicans seeking federal office.

This opposition to reproductive choice has been most successful in banning federal funding for abortion. ${ }^{44}$ The original 1976 federal funding ban was restricted to poor women. That ban has since been extended to all abortions for federal employees, military personnel, disabled Medicare beneficiaries, federal prisoners and Peace Corps volunteers. Even after implementation of the Affordable Care Act (ACA) in 2010, making health insurance available to all citizens for the first time in U.S. history, federal funding for abortion is still prohibited. Opposition to reproductive choice is not limiting to funding, however. Many states place burdensome regulations on women seeking abortions and doctors who provide them. Doctors are subject to threats of violence, and some have been killed. While pro-choice forces resist, the outcome of this battle remains unclear. ${ }^{45}$

Lack of health insurance coverage for childbirth and contraception also compromises women's liberty and equality. Traditionally, insurance coverage was denied on grounds that these were cosmetic, lifestyle services, not medical needs. In the 1990s, liberal feminists persuaded state legislators that such exclusions discriminated on the basis of gender and that coverage made sense from the perspective of health, money and women's dignity. Workers persuaded their unions or employers, and students and teachers persuaded their schools, to include contraception in their insurance plans. Some federal courts held that the Pregnancy Discrimination Act prohibited exclusion of contraception from otherwise comprehensive coverage for prescription drugs, illegally discriminating against women. ${ }^{46}$

All of the legal tools for feminist reform were enhanced by the mobilization of popular cultural support. Between 1999 and 2009 the proportion of employment-based health insurance plans that covered prescriptive contraception rose from 30 percent to 90 percent. ${ }^{47}$ After implementation of the ACA, insurance coverage was again expanded. The ACA required that plans cover 'preventive care and screenings' without cost sharing, including preventive services and screenings for women as recommended by the Health Resources and Services Administration (HRSA). ${ }^{48}$ In 2011, following

43 Williams, supra note 41 , at 532.

44 See Copelon and Law, supra note 21.

45 See, e.g., Eric Eckholm, Texas Ruling on Abortion Leads to Call for Clarity, N.Y. TIMES (June 10, 2015) https://www.nytimes.com/2015/06/11/us/clarity-sought-on-undue-burdenstandard-for-abortion-laws.html.

46 See, e.g., Erickson v. Bartell Drug Co., 141 F. Supp. 2d 1266, 1276 (W.D. Wash. 2001).

47 Cynthia Dailard, Contraceptive Coverage: A 10-Year Retrospective, GUTTMACHER INSTITUTE (June 10, 2004) https://www.guttmacher.org/gpr/2004/06/contraceptive-coverage-10-yearretrospective.

48 The ACA contains a section on the coverage of preventative services. Patient Protection and Affordable Care Act of 2010, Pub. L. 111-14, § 1001 (adding § 2713 to the Public Health Service Act) (codified as 42 U.S.C. §300gg-13 (2012)). It also includes a separate section outlining Essential Health Benefits, which include preventative services. 42 U.S.C. $\$ 18022$ 
consultation with the Institute of Medicine, HRSA determined that a review of evidence-based preventive services data required that insurance plans cover a wide range of contraceptive methods.

Though the coverage standards were broad, their implementation was not. In compliance with long-standing Internal Revenue Service regulatory policy, the Department of Health and Human Services (HHS) granted an exemption to "churches, their integrated auxiliaries, and conventions or associations of churches, as well as the exclusively religious activities of any religious order.' ${ }^{49}$ In addition, the rules created an accommodation, rather than an outright exemption, for certain non-profit organizations that hold themselves out as religious organizations and object on religious grounds to including some or all contraceptive services in the services they provide to employees, students or clients. Organizations eligible for the accommodation had to file a one-page form with their health insurance issuer, which was then required to provide payment for contraception for women in the plan at no cost to the women or to the organization. The accommodation was designed to ensure that women continued to receive the coverage to which they were entitled while effectively taking the religious employer out of the picture. The federal government assumed that insurers would absorb the cost of coverage on the theory that their outlays would be offset by the savings achieved from the prevention of unintended pregnancy.

Many employers challenged the regulations. The first case to reach the Supreme Court was Burwell v. Hobby Lobby Stores (Hobby Lobby), decided in 2014..$^{50}$ The lawsuit was brought by a closely held, for-profit corporation that argued that the federal Religious Freedom Restoration Act (RFRA) protected its right to refuse to provide employees insurance coverage for contraception. RFRA provides that the '[g]overnment shall not substantially burden a person's exercise of religion even if the burden results from a rule of general applicability,' unless the burden is 'in furtherance of a compelling government interest' and the challenged law is 'the least restrictive way in which to further the government interest.' 51

For the first time in history, Justice Samuel Alito, writing for a 5-4 majority, found that profit-making corporations are entitled to claim protection for the free exercise of religion. He conceded, for the purpose of the case, that the government had a compelling interest in assuring that women have access to the full range of contraceptives, but he did not explore the nature of that interest. In her dissent, Justice Ginsburg quoted Planned Parenthood v. Casey, which recognized that ' $[t]$ he ability of women to participate equally in the economic and social life of the Nation has been facilitated by their ability to control their reproductive lives.' ${ }^{52}$ She further observed 'that the cost of

(2012). See also Women's Preventive Services Guidelines, Health Res. \& Servs. Admin., https://www.hrsa.gov/womensguidelines/.

49 Group Health Plans and Health Insurance Issuers Relating to Coverage of Preventive Services Under the Patient Protection and Affordable Care Act, 78 Fed. Reg. 8456, 8461 (Feb. 6, 2013).

50 Burwell v. Hobby Lobby Stores, Inc., 134 S. Ct. 2751, 2788 (2014).

5142 U.S.C. $\$ 2000 b b-1(a)$, (b) (1993).

52 Hobby Lobby, 134 S. Ct. at 2788 (Ginsburg, J., dissenting); see also Planned Parenthood of Southeastern Pa. v. Casey, 505 U.S. 883, 856 (1992). 


\section{Research handbook on feminist jurisprudence}

an IUD is nearly equivalent to a month's full-time pay for workers earning the minimum wage.' 53

The pivotal holding, which won the decisive fifth vote from Justice Anthony Kennedy, was that there was a less restrictive way to promote the compelling government interest without burdening the plaintiffs' religious objections. Secular, profit-making corporations could be offered the 'accommodation' given to religious non-profits. ${ }^{54}$ In the years that Hobby Lobby was pending, eight Circuit Courts of Appeals considered claims from religious non-profit organizations arguing that the requirement to notify their insurers that they had religious objections was a violation of RFRA. Seven Circuits concluded that the requirement to file a notice imposed no significant burden on the exercise of religion. ${ }^{55}$ One Circuit held that the requirement to file a notice declining contraception coverage burdened religious freedom by making the employer complicit in the use of birth control and that the notice requirement was not the least restrictive alternative because the government could create a publicly funded program or offer separate, subsidized contraception policies to employees of objecting organizations. ${ }^{56}$ Given the Court's seeming endorsement of the Hobby Lobby accommodation then in effect, many were surprised when, three days after the Hobby Lobby decision, the Court granted certiorari in the pending cases and issued an injunction urging the parties to find a compromise. ${ }^{57}$

With the election of Trump, the picture changed. The Administration leaked new rules in May 2017 and issued Interim Federal Rules (IFRs) on October 13, 2017. ${ }^{58}$ The new IFRs expanded accommodations, which were already available to non-profit religious employers and closely held corporations controlled by people with religious objections, to include profit-making enterprises. The rules also added 'moral objection' as a legitimate reason for excluding coverage for contraception, thus expanding the accommodation to cover both moral and religious objections. Moreover, employers who take advantage of the accommodation no longer have to provide any form of notice to the government or to their employees in order to allow responsibility for coverage to be assumed by the insurer or the claims administrator. Rather, changes in coverage only need to be reflected in plan documents, requiring employees to monitor these documents, which are ever-changing and often difficult to find.

The regulations are bizarre, both substantively and procedurally. Substantively, the IFRs rejected the factual findings of the Institute of Medicine and rely instead on the

\footnotetext{
53 Hobby Lobby, 134 S. Ct. at 2800.

54 Id. at 2760.

55 See, e.g., Notre Dame Univ. v. Burwell, 786 F.3d 606 (7th Cir. 2015).

56 Geneva Coll. v. Sec'y U.S. Dep't of Health \& Human Servs., 778 F3d. 422 (3d Cir. 2015).

57 Wheaton Coll. v. Burwell, 134 S. Ct. 2806 (2014).

58 Religious Exemptions and Accommodations for Coverage of Certain Preventive Services Under the Affordable Care Act, 82 Fed. Reg. 47792 (2017), https://www.gpo.gov/fdsys/pkg/FR2017-10-13/pdf/2017-21851.pdf; Moral Exemptions and Accommodations for Coverage of Certain Preventive Services Under the Affordable Care Act, 82 Fed. Reg. 47838 (2017), https://www.gpo.gov/fdsys/pkg/FR-2017-10-13/pdf/2017-21852.pdf.
} 
sole dissenting member of the committee.59 For example, the IFRs discounted statistical evidence that access to contraception correlates with decreased rates of unintended pregnancy, observing that correlation does not equal causation. Additionally, they asserted that most forms of contraception were available for $\$ 50$ a month, ignoring evidence that more effective forms required higher up-front costs and that \$50 a month was a significant financial cost to most American women. The IFRs further stated that the women 'most at risk' of unintended pregnancy were young, unmarried, low-income minority women, who were not the kind of women who had employer-based group health coverage or attended private universities. This of course ignores that all sexually active women of childbearing age are at risk of unintended pregnancy. Perhaps most preposterously, the IFR observed that increased access to contraceptives could 'exacerbate the long run negative effects of changing sexual behavior by, for example, providing contraceptive access to teenagers and young adults who are not necessarily in the sexually active at-risk population of women.' These are only a few examples of the rejection of the National Academy of Medicine's evidence-based responses to all these claims. ${ }^{60}$

Procedurally, the IFRs were even stranger. The federal regulators issued the new rules as IFRs on October 6, 2017, effective 60 days after publication in the Federal Register, and requested post-issuance comments by December 5, 2017. There was no pretense of compliance with the notice-and-comment procedures required by the Administrative Procedure Act (APA). New York, California and other states filed federal court challenges to the new IFRs and the process through which they came about. On December 15, 2017, Pennsylvania Federal District Judge Wendy Beetlestone became the first to hold the Trump contraception regulations illegal. ${ }^{61}$ On the procedural issues, she rejected the Trump claim that there was an emergency that justified departure from standard APA process. ${ }^{62}$ On the substance, Judge Beetlestone noted the 'remarkable breadth' of the moral objection: '[any corporation] can deny contraceptive coverage for the corporation's women employees not just for religious reasons but also for any inchoate - albeit sincerely held - moral reason they can articulate.' ${ }^{3}$ Of the new 'moral objection', the judge asked, 'Who determines whether the expressed moral reason is sincere or not or, for that matter, whether it falls within the bounds of morality or is merely a preference choice?' She observed that 'the Administration has conjured up a world where a government entity is empowered to impose its own version of morality on each one of us.' ${ }^{4}$ The IFR also provided that the requirement that objecting employers provide notice to insurance carriers or the government imposed a substantial burden on religious freedom under RFRA. Judge

59 See id. To read Dr. Lo Sasso's dissenting opinion, see InSTITUTE OF MEDICINE OF THE National ACAdemies, Clinical Preventive Services for Women: Closing the Gaps 231-35 (2011), https://www.nap.edu/read/13181/chapter/14.

60 Id.

61 Commonwealth v. Trump, No. 17-4540, 2017 U.S. Dist. LEXIS 206380 (D.Pa. Dec. 15, 2017).

$\begin{array}{ll}62 & I d . \text { at } * 40 . \\ 63 & I d . \text { at } * 44 . \\ 64 & I d .\end{array}$ 
Beetlestone noted that federal courts had rejected that claim and that judicial findings cannot be reversed by regulation. ${ }^{65}$

The struggle over access to contraceptives is not solely about federal laws, regulations and judicial decision, though those are important. It is also about mobilization on the ground, resistance, facts and evidence. In 2013 the University of Notre Dame sued the federal government, challenging the requirement that it notify its insurer that it did not want to provide its employees the contraceptive coverage required by the ACA. ${ }^{66}$ It lost that case. In 2018, when the Trump Administration notified Notre Dame that it no longer needed to either provide coverage for contraception or send a one-page notice to its insurer, the university informed all faculty and staff that contraception was no longer included in their health plan. A week later, Notre Dame changed its mind and informed employees that contraception would be covered, without cost sharing. The university explained its sudden reversal as it came to recognize 'the plurality of religious and other convictions among its employees.' ${ }^{67}$

Consideration of health insurance coverage for contraception can be read as a testament to the power of the liberal values of separation of powers, judicial review and grass-roots engagement to assure implementation on the ground. Alternatively, it can be read as a tale of the fragility of liberal feminism. After Griswold held in 1965 that the Constitution protects married couples' right to use contraception, and the Supreme Court extended that right to single people in 1972, one might have assumed that contraception would be treated like other medical services. That assumption proved wrong. As health care costs rose and insurance coverage, public and private, became essential, contraception was routinely excluded from private insurance until the 1990s, when liberal feminists mobilized to persuade employers, state legislators and courts that this exclusion was irrational in terms of health, insurance costs and the burdens disproportionately imposed on women. ${ }^{68}$ The ACA expanded that development. The end of this story has not yet been written.

\section{B. Sexual Harassment Law and Backlash}

A second form of backlash to liberal feminism can be seen through the lens of the \#MeToo movement, which focuses on sexual harassment. Sexual harassment of working women is not a new issue to liberal feminists and indeed was a prominent issue on the agenda of Second Wave feminists. In 1979, Catharine MacKinnon brilliantly documented that the sexual harassment of working women was widely practiced, systematically ignored and constituted illegal gender discrimination under

\footnotetext{
$65 \quad I d$. at $* 51$.

66 Univ. of Notre Dame v. Sebelius, 988 F. Supp. 2 d. 912 (N.D. Ind. 2013).

67 Christina Cauterucci, Notre Dame Reverses Its Stance on Birth Control Coverage for Employees, Slate (Nov. 7, 2017), http://www.slate.com/blogs/xx_factor/2017/11/07/notre_ dame_reverses_its_stance_on_birth_control_coverage_for_employees.html; Emma Green, Why Notre Dame Reversed Course on Contraception, ThE ATlanTIC (Nov. 8, 2017), https:// www.theatlantic.com/politics/archive/2017/11/notre-dame-birth-control-obamacare-reversal/5452 $82 \%$

68 See Sylvia A. Law, Sex Discrimination and Insurance for Contraception, 73 WASH. L. REV. 363 (1998).
} 
Title VII of the Civil Rights Act of $1964 .{ }^{69}$ In 1980 the Equal Employment Opportunity Commission (EEOC) issued regulations defining sexual harassment and stating it was a form of sex discrimination prohibited by the 1964 Civil Rights Act, and the Supreme Court recognized sexual harassment as a violation of Title VII in 1986. ${ }^{70}$ The Court characterized unwelcomeness as the gravamen of any sexual harassment claim. Moreover, 'voluntariness' was deemed irrelevant because an employee can feel compelled to acquiesce to unwelcome sexual attention to avoid termination, the very situation gender discrimination law seeks to avert. ${ }^{71}$ Despite sexual harassment being recognized as illegal sex discrimination, it remains pervasive. Each year in the early twenty-first century, the EEOC and related state agencies received over 10,000 new charges of sexual harassment on the job. ${ }^{72}$

The 2016 Presidential election put a new focus on the pervasiveness of sexual harassment. On October 7, 2016, just before the election, the Washington Post published a video of candidate Trump bragging to television host Billy Bush about sexually assaulting women: 'I don't even wait. And when you're a star, they let you do it, you can do anything ... grab them by the pussy.' ${ }^{\prime 3}$ He subsequently 'apologized' explaining, "[t]his was locker room banter, a private conversation that took place many years ago. Bill Clinton has said far worse to me on the golf course - not even close. I apologize if anyone was offended.' 74

The public response was immediate. Legal experts opined that the behavior Trump described constituted criminal sexual assault in most states; Republicans called for him to step down in the Presidential race; and dozens of women filed legal complaints against him. ${ }^{75}$ On the day after Trump's inauguration, women gathered around the world to oppose his policies and to support women's rights, as well as other rights. The Women's March in Washington, D.C. was the largest protest in U.S. history. ${ }^{76}$ Despite this large public outcry, Trump refused to issue a true apology or take a stand against

69 Catharine A. MacKinnon, Sexual Harassment of Working Women (1979).

70 Meritor Savings Bank v. Vinson, 477 U.S. 57 (1986).

71 See Tanya K. Hernández, 'What Not to Wear' - Race and Unwelcomeness in Sexual Harassment Law: The Story of Meritor Savings Bank v. Vinson, in WOMEN AND THE LAW: STORIES 277 (Elizabeth M. Schneider and Stephanie M. Wildman eds., 2011).

72 Equal Employ't OpPoRtunity COMM'N, Charges Alleging Sex-Based Harassment FY 2010-FY 2016, https://www.eeoc.gov/eeoc/statistics/enforcement/sexual_harassment_new.cfm.

73 Trump Recorded Having Extremely Lewd Conversation About Women in 2005, WASH. PosT (Oct. 8, 2016), https://www.washingtonpost.com/politics/trump-recorded-having-extremelylewd-conversation-about-women-in-2005/2016/10/07/3b9ce776-8cb4-11e6-bf8a-3d26847eeed4_ story.html?tid=a_mcntx\&utm_term=.ec4575efe $7 \mathrm{bb}$.

74 Aaron Blake, Donald Trump Finally Said Something So Bad He Had to Apologize, WASH. Post (Oct. 8, 2016), https://www.washingtonpost.com/news/the-fix/wp/2016/10/07/ donald-trump-finally-said-something-so-bad-he-had-to-apologize-kind-of/?tid=a_mcntx\&utm_ term=.dad2a4ed0879.

75 Megan Twohey, Trump's Female Accusers Feel Forgotten. A Lawsuit May Change That, N.Y. TIMES (Nov. 1, 2017), https://www.nytimes.com/2017/11/01/us/politics/trumps-femaleaccusers-feel-forgotten-a-lawsuit-may-change-that.html.

76 Leanna Garfield, The 11 Biggest Marches and Protests in American History, Bus. INSIDER (Feb. 8, 2017), http://www.businessinsider.com/largest-marches-us-history-2017-2/\#themarch-on-washington-for-jobs-and-freedom-august-28-1963-1. 
sexual harassment. Indeed, over a year after the release of the tape, President Trump suggested that the tape was a 'fake.' 77 Billy Bush, who was fired from his job as host of the Today Show for his role in the tape, responded in a New York Times Op-Ed, 'Yes, Donald Trump, You Said That.' Bush acknowledged that he and the other men on the bus 'were guilty of sacrificing a bit of ourselves in the name of success.' ${ }^{78}$

In October 2017, the New York Times and the New Yorker reported that dozens of women had accused the prominent movie producer, Harvey Weinstein, of sexual abuse over decades. ${ }^{79}$ More than 80 women in the film industry subsequently accused Weinstein of such acts. He was dismissed by the Weinstein Company, which he co-owned, and expelled from the Academy of Motion Picture Arts and Sciences. At the time of writing, criminal investigations are ongoing in Los Angeles, New York City and London.

Soon after the Weinstein scandal, the \#MeToo movement exploded. On October 15, 2017, actress Alyssa Milano tweeted 'If you've been sexually harassed or assaulted write "me too" as a reply to this tweet." ${ }^{80}$ By the next day, millions of people used \#MeToo on Twitter, Facebook and other social media platforms. ${ }^{81}$ In the social media firestorm, it was revealed that 'Me Too' was created in 2007 by Tarana Burke. Burke is an African-American women's rights activist who leads a non-profit organization, Just Be Inc., that helps young survivors of sexual harassment and assault. Burke called her work 'Me Too.' After Milano learned about the original \#MeToo movement, she tweeted a link to Just Be Inc.'s website. ${ }^{82}$

At first, those speaking out were mostly from the worlds of media and entertainment, but the hashtag quickly spread. By November, California farm workers were marching on the streets of Hollywood to express their solidarity with celebrities. In December,

77 Aaron Blake, Trump Is Reportedly Suggesting the 'Access Hollywood' Tape Is Fake News. He Should Talk to 2016 Trump, WASH. Post (Nov. 27, 2017), https://www.washington post.com/news/the-fix/wp/2017/11/27/trump-is-reportedly-saying-the-access-hollywood-tape-wasfake-news-he-should-talk-to-2016-trump/?utm_term=.65a57e8141e6.

78 Billy Bush, Billy Bush: Yes, Donald Trump, You Said That, N.Y. Times (Dec. 3, 2017), https://www.nytimes.com/2017/12/03/opinion/billy-bush-trump-access-hollywood-tape.html.

79 Jodi Kantor and Megan Twohey, Harvey Weinstein Paid Off Sexual Harassment Accusers for Decades, N.Y. TimES (Oct. 5, 2017), https://www.nytimes.com/2017/10/05/us/harveyweinstein-harassment-allegations.html; Ronan Farrow, From Aggressive Overtures to Sexual Assault: Harvey Weinstein's Accusers Tell Their Stories, THE NEW YoRKER (Oct. 10, 2017), https://www.newyorker.com/news/news-desk/from-aggressive-overtures-to-sexual-assault-harveyweinsteins-accusers-tell-their-stories.

80 Alyssa Milano (@Alyssa_Milano), TwiTTER (Oct. 15, 2017; 1:21 PM), https://twitter. com/Alyssa_Milano/status/919659438700670976/photo/1?ref_src=twsrc\%5Etfw\&ref_url=https $\% 3 \mathrm{~A} \% 2 \mathrm{~F} \% 2 \mathrm{Fwww}$.nytimes.com\%2F2017\%2F10\%2F20\%2Fus\%2Fme-too-movement-taranaburke.html.

81 Sandra E. Garcia, The Woman Who Created \#MeToo Long Before Hashtags, N.Y. TIMES (Oct. 20, 2017), https://www.nytimes.com/2017/10/20/us/me-too-movement-tarana-burke.html.

82 Alyssa Milano (@Alyssa_Milano), TwitTer (OcT. 16, 2017; 4:24 PM), https://twitter. com/Alyssa_Milano/status/920067975016624128?ref_src=twsrc\%5Etfw\&ref_url=https\%3A\%2F $\% 2$ Fwww.bostonglobe.com $\% 2$ Flifestyle $\% 2 \mathrm{~F} 2017 \% 2 \mathrm{~F} 10 \% 2 \mathrm{~F} 17 \% 2 \mathrm{Falyssa}$-milano-credits-activisttarana-burke-with-founding-metoo-movement-years-ago\%2Fo2Jv29v6ljObkKPTPB9KGP\%2F story.html. 
Time magazine honored the Silence Breakers as the 2017 Person of the Year. ${ }^{83}$ Of course, 'the paradox is that, in many cases, those women were not silent at all. It was that nobody listened when they spoke.' ${ }^{84}$ Even though many of the publicized cases involved public figures, harassment of women is often worse for economically vulnerable women and women of color, and it is not limited to sex. ${ }^{85}$ Indeed, after the Silence Breakers were named Time's Person of the Year, Burke noted, 'We have to keep our focus on people of different class and race and gender.' 86

It is still too soon to know the impact of the \#MeToo movement on the behavior of men, women and society. Yet the history of liberal feminism holds a few lessons regarding these dramatic developments. First, here as elsewhere, legal rules prohibiting sexual harassment are necessary, but never alone sufficient. Broader cultural changes are needed to allow women to speak and be heard, to educate men like Donald Trump and Harvey Weinstein that their behavior is harmful and wrong and to discourage those who are complicit in their wrongful behavior. ${ }^{87} \mathrm{~A}$ major lesson of the struggle for marriage equality was that empathy and respect were difficult as long as people, particularly those in positions of power, could say, 'I've never met a gay person.' Similarly, progress in relation to abortion rights has been difficult because the reality of abortion was and remains a secret in both private life and popular culture. ${ }^{88}$ In short, \#MeToo has sparked a broad, constructive conversation.

Second, liberal feminism, like liberalism, demands reliance on facts, evidence and due process. Much of the conversation triggered by \#MeToo has focused on the interests of men accused of sexual harassment. New York Senator Kirsten Gillibrand was the first senator to call on her colleague, Al Franken, to resign. The allegations against Franken were mild compared to the actions of Trump or Weinstein. Gillibrand asserted, 'when we have to start talking about the differences between sexual assault and sexual harassment and unwanted groping, you are having the wrong conversation. You need to draw a line in the sand and say none of it is O.K.' ${ }^{89}$ Zephyr Teachout responded, saying that zero tolerance for sexual harassment should go hand in hand with due process and proportionality: '[P]roportionality means that while all forms of inappropriate sexual behavior should be addressed, the response should be based on the

83 Stephanie Zacharek, Eliana Dockterman and Haley S. Edwards, Person of the Year 2017: The Silence Breakers, TIME, http://time.com/time-person-of-the-year-2017-silence-breakers/.

84 Jessica Bennett, The \#MeToo Moment: No Longer Complicit, N.Y. TIMES (Dec. 7, 2017), https://www.nytimes.com/2017/12/07/us/the-metoo-moment-no-longer-complicit.html.

85 Susan Chira, We Asked Women in Blue-Collar Workplaces About Harassment. Here Are Their Stories., N.Y. TimES (Dec. 29, 2017), https://www.nytimes.com/2017/12/29/us/blue-collarwomen-harassment.html.

86 The Silence Breakers, supra note 83.

87 Megan Twohey et al., Weinstein's Complicity Machine, N.Y. TIMES (Dec. 5, 2017), https://www.nytimes.com/interactive/2017/12/05/us/harvey-weinstein-complicity.html.

88 Scott Skinner-Thompson, Sylvia A. Law and Hugh Baran, Marriage, Abortion and Coming Out, 116 Colum. L. REv. ONLINE 126 (2016), http://columbialawreview.org/content/ marriage-abortion-and-coming-out/.

89 Shane Goldmacher, On Sexual Misconduct, Gillibrand Keeps Herself at the Fore, N.Y. TiMES (Dec. 6, 2017), https://www.nytimes.com/2017/12/06/nyregion/gillibrand-franken-sexualmisconduct.html. 
nature of the transgressions.' 90 Current procedures for dealing with harassment accusations are utterly inadequate in Congress as well as in most U.S. institutions. This is a complex discussion and beyond the scope of this chapter, but the urgent liberal legal work of demanding accountability combined with due process will now be better informed by the voices of \#MeToo.

\section{Economic Inequality and Liberal Feminism}

In addition to reproductive choice and sexual harassment, a third, core, twenty-firstcentury challenge for liberalism, feminism and the movement for racial equality is presented by the gross disparities in economic opportunities, wealth and income, based not on ability to perform and contribute, but rather on race and gender. In the months before he was assassinated in 1968, Martin Luther King sharply condemned these growing disparities and drew connections between racial equality and economic equality. ${ }^{91}$ Looking back, we know that the period from the end of World War II until the mid-1970s was an unusual golden moment of economic growth and growing relative economic equality, both in the United States and around the world. Since that time, disparities in wealth, income and economic opportunity have become dramatically worse. ${ }^{92}$ In 1965, the average U.S. CEO earned 20 times more than the average worker in his firm; in 2014, he earned 303 times more. ${ }^{93}$

The relationship between liberalism and economic inequality is complex. In the agrarian economy of the eighteenth century, classic liberalism placed a high value on private property, free markets and freedom of contract. With urbanization and industrialization in the late nineteenth century, states and the federal governments adopted limited measures to ameliorate the harshest excesses of capitalism and protect vulnerable workers. Until 1937, the U.S. Supreme Court, in the name of liberalism embodied in the Constitution, struck down these modest efforts. ${ }^{94}$ The Great Depression and the New Deal response produced a sea change in the understanding of constitutional liberalism. Since 1937, the U.S. Supreme Court has broadly held that

90 Zephyr Teachout, I'm Not Convinced Franken Should Quit, N.Y. TiMES (Dec. 11, 2017), https://www.nytimes.com/2017/12/11/opinion/franken-resignation-harassment-democrats.html.

91 Dr. Martin Luther King addressed these issues at my commencement from Antioch College in June 1965. Audio of his speech available at http://wyso.org/post/revisiting-dr-martinluther-king-jrs-1965-commencement-speech-antioch-college.

92 See, e.g., Emily Badger, Whites Have Huge Wealth Edge Over Blacks (But Don't Know It), N.Y. TIMES (Sept. 18, 2017), https://www.nytimes.com/interactive/2017/09/18/upshot/blackwhite-wealth-gap-perceptions.html; Changes in U.S. Family Finances from 2013 to 2016: Evidence from the Survey of Consumer Finances, 103 FED. RES. BULL. 1, 10 (2017), https://www.federalreserve.gov/publications/files/scf17.pdf ('The wealth share of the top 1 percent climbed from 36.3 percent in 2013 to 38.6 percent in $2016 \ldots$ the wealth share of the bottom 90 percent of families has been falling over most of the past 25 years, dropping from 33.2 percent in 1989 to 22.8 percent in 2016').

93 Lawrence Mishel and Alyssa Davis, Top CEO's Make 300 Times More than Typical Workers, ECON. POL'Y INST. (June 21, 2015), http://www.epi.org/publication/top-ceos-make-300times-more-than-workers-pay-growth-surpasses-market-gains-and-the-rest-of-the-0-1-percent/.

94 See, e.g., Lochner v. New York, 198 U.S. 45 (1905) (striking down a New York law setting maximum hours for bakers on the ground that it violated freedom of contract). 
economic regulation is a matter of political choice, stating that 'a constitution is not intended to embody a particular economic theory,' 95 and courts should defer to legislative judgments in the adoption of economic regulation.

The Constitution gives the political branches, 'the voice of the people,' great latitude to choose between policies that promote economic security and opportunity for all and policies that favor private capital accumulation and historic wealth. In the New Deal era, Democrats favored progressive taxation and other policies promoting economic equality and public social services and embraced a liberal identity. In the 1980s, conservative leaders, including Ronald Reagan in the United States, Margaret Thatcher in Great Britain and Augusto Pinochet in Chile, appropriated the mantle of 'liberalism.' Defining themselves as 'Neo-Liberals,' they promoted policies of fiscal austerity, deregulation, privatization, free trade and reductions in public spending. ${ }^{96}$ At the same time, many Democrats, who once identified as liberals, now often define themselves as 'fiscally conservative' and socially liberal. In short, the meaning of 'liberalism' in relation to economic justice is contested.

Like liberalism, feminism does not have a core consensus position on issues of economic equality and opportunity. However, like other movements on behalf of historically oppressed and marginalized people, including movements for racial justice, LGBTQ liberation and people with disabilities and immigrants, feminism often focuses on issues of economic fairness and seeks to promote the welfare of women and the economically vulnerable. One twenty-first-century liberal feminist effort to address economic inequality focused on the situation of people, overwhelmingly women, racial minorities and immigrants, who perform the vital work of caring for the vulnerable young and old. ${ }^{97}$ It illustrates some of the strengths and weaknesses of liberal feminism.

The classic eighteenth-century liberal assumption that women perform the essential work of caring for those who need help because of youth, age or disability remains largely intact. Women at the top of the economic ladder hire other women to help care for their families. In the Depression of the 1930s, Congress first set a national minimum wage and rules for overtime pay and passed the Fair Labor Standards Act. The political compromise thought necessary to pass the Fair Labor Standards Act in 1938 required exemptions for domestic and agricultural workers. Obviously, those workers need the protection of a minimum wage more than most. But they were and are politically weak, in significant part precisely because they are disproportionately women, people of color and immigrants.

In the 1970s Congress amended the law to correct this racial and gender-based discrimination and extend the minimum wage protections to domestic and home health care workers. However, the Department of Labor never implemented the authorized changes. In 2011 organized domestic workers persuaded the Obama Administration to adopt the protections that Congress had authorized. After employers fought back, a

95 Id. at 75 (Holmes, J., dissenting).

96 See Monica Prasad, The Politics of Free Markets: The Rise of Neoliberal Economic Policies in Britain, France, Germany and the United States (2006).

97 See Peggie R. Smith, Regulating Paid Household Work: Class, Gender, Race, and Agendas of Reform, 48 AM. U. L. REV. 851 (1999). 
federal court battle ensued, delaying implementation of the rules until January 2016.98 It is unclear whether these protections will remain in place under the Trump Administration. ${ }^{99}$

The situations of older people who need home care and of those who provide it pose a serious challenge to feminists in the twenty-first century. Both groups are hugely, disproportionately, women. Ninety percent of older adults want to stay in their home as they age, and assisted home care is often less costly than institutional alternatives. But for many, paid home care workers are essential to enable them to remain at home. ${ }^{100}$ Indeed, as the population ages, the need for home health care workers grows at a rate five times faster than the rate of overall job growth. ${ }^{101}$ Home care wages, however, are poverty wages, with average annual earnings of just $\$ 18,598$. Moreover, most home health care workers do not have benefits, paid time off or paid sick time. Schedules and hours are unpredictable, and nearly half of home care workers are not offered full-time or consistent work. The struggles of the past provide the tools for this fight and a cadre of people skilled at mobilizing them, but it is unclear when this fight will be won.

\section{CONCLUSION}

Liberal feminism has been criticized by the political right and feminists alike. ${ }^{102}$ Liberal feminism is often depicted as pathetically anemic by its critics, as a feminist theory that demands recognition and protection of women's individual autonomy, rights to full equality, dignity and respect. This chapter seeks to articulate a more complex vision of liberal feminism. Liberal rights are never, alone, sufficient to achieve justice. Rights are, however, an important part of the struggle for justice, particularly for vulnerable people.

Edward V. Sparer, a principal founder of civil legal services in the United States, primary architect of the concept that welfare, Medicaid, Medicare and food stamps are entitlements deserving of the protections granted to the property of the more affluent and General Counsel to the National Welfare Rights Organization when it flourished,

98 Home Care Ass'n of America v. Weil, No. 15-5918 (D.C. Cir. 2015).

99 Ben Penn, Home-Care Industry Wants Wage Rule Reversed by Trump Labor Chief, BLOOMBERG News (Apr. 12, 2017), https://www.bna.com/homecare-industry-wants-n579820 $86560 /$.

100 E. Tammy Kim, Americans Will Struggle to Grow Old at Home, BloOMBERG BusinessWEEK (Feb. 9, 2018), https://www.bloomberg.com/news/features/2018-02-09/americans-willstruggle-to-grow-old-at-home.

101 Caitlin Connolly, Aging in Place Will Require Investing in Home Care Workers, NAT'L EMP. L. PROJECT (May 14, 2015), http://www.nelp.org/publication/aging-in-place-will-requireinvesting-in-home-care-workers/.

102 See, e.g., Robin Morgan, Light Bulbs, Radishes and the Politics of the 21st Century, in Radically Speaking: Feminism ReClaimed 5 (Diane Bell and Renate Klein eds., 1996); Denise Schaeffer, Feminism and Liberalism Reconsidered: The Case of Catharine MacKinnon, 95 Am. Pol. SCI. ReV. 699 (2001); Dorothy Roberts, Reproductive Justice, Not Just Rights, DisSENT MAG. (Fall 2015), https://www.dissentmagazine.org/article/reproductive-justice-notjust-rights; Lynn M. Paltrow and Jeanne Flavin, Arrests of and Forced Interventions on Pregnant Women in the United States, 1973-2005: Implications for Women's Legal Status and Public Health, 38 J. Health Pol., Pol'Y. \& L. 299 (2013). 
died prematurely in 1983. At the time of his death, he was writing an article responding to claims that liberal rights are incoherent and inherently conservative. His complex response was that liberal rights are limited, imperfect, and insufficient, but nonetheless important. ${ }^{103}$

Crystal Eastman, an early twentieth-century American feminist, also captured the power and frustrations of liberal feminism. Eastman was a leader in the suffrage movement, a prime actor in the movement to create a compensation system for injured workers, a founder of the American Civil Liberties Union, and leader of the Women's Peace Party and the American Union Against Militarism. Early in her career, Eastman led the effort to create workers' compensation systems to provide reliable compensation to injured workers and their families. She richly documented the need for compensation in a world where work was unnecessarily dangerous and common law concepts systematically denied workers the ability to sue for injury. She analyzed thencontroversial questions of state power to create alternative remedies and developed a popular and constitutional consensus for reform, and her multifaceted efforts with unions, industrialists and others persuaded many states to adopt workers' compensation.

Even as Eastman succeeded in winning compensation for injured workers, however, she argued that compensation was inadequate when injuries were preventable.

When the strong young body ... is caught up by the little projecting-set-screws, whirled around a shaft and battered to death ... when we know that the law of the state has prohibited set-screws for many years, then who wants to talk about 'three years' wages to the widow, and 'shall it be paid in installments, or in lump sum?' ... What we want is to start a revolution.

Having identified the need for a revolution, Eastman proceeded to detail an accidentprevention program that relied on state regulation, data, transparency and vigorous enforcement: 'The first thing we need is information ... It seems a tame thing to drop so suddenly from talk of revolutions to talk of statistics. But I believe in statistics just as firmly as I believe in revolution. ' ${ }^{104}$ This is classic liberal feminism.

With respect to reproductive freedom, Eastman argued that there were two central 'facts of feminism': economic independence from men and birth control.

Feminists are not nuns ... We want to love and be loved ... We want our children to be deliberately, eagerly called into being, when we are at our best, not crowded upon us in times of poverty and weakness. We want this precious sex knowledge not just for ourselves, the conscious feminists; we want it for all the millions of unconscious feminists that swarm the earth, - we want it for all women.

Eastman reminds us, 'Life is a big battle for the complete feminist even when she can regulate the size of her family.' ${ }^{105}$

103 Edward V. Sparer, A Friendly Critique of the Critical Legal Studies Movement, 36 STAN. L REV. 509, 524 (1984).

104 Quoted in Sylvia A. Law, Crystal Eastman: NYU Law Graduate, 66 N.Y.U. L. REV. 1963, 1994 (1991).

105 Crystal Eastman, Birth Control in the Feminist Program, BIRTH CONTROL Rev. (1918), reprinted in ON WOMEN AND REVOLUTION 46 (Blanche Wiesen Cook ed., 1978). 